\title{
Implementasi Pendidikan Inklusif Pada Lembaga Pendidikan Anak Usia Dini Di Indonesia
}

\author{
Syahria Anggita Sakti ${ }^{1}$ \\ PG PAUD Universitas PGRI Yogyakarta \\ Email: anggitosakti86@gmail.com ${ }^{1}$
}

\begin{abstract}
Abstrak
Penelitian ini bertujuan untuk menganalisis sejauh mana implementasi pendidikan inklusi pada lembaga pendidikan anak usia dini di Indonesia. Pendidikan inklusi pada anak usia dini dimulai dengan mengakomodasi kebutuhan anak, mengidentifikasi kebutuhan khusus anak, serta memetakan potensi perkembangan dan hambatan anak saat ini maupun di masa depan. Pendidikan inklusif senantiasa mengedepankan aspek kesetaraan bagi anak berkebutuhan khusus untuk memperoleh layanan pendidikan. Praktek sistem pendidikan inklusif yang di implementasikan pada tingkatan pendidikan anak usia dini masih menyisakan persoalan, yakni pelaksanaan pendidikan inklusif yang ternyata masih tidak inklusif. Persoalan tenaga pendidik, sarana prasarana pendukung, serta kurikulum pendidikan inklusif pada lembaga pendidikan anak usia dini juga belum mumpuni. Pendidikan inklusi di Indonesia harus melibatkan orang tua, guru dan lingkungan pembelajaran. Implementasi pendidikan inklusif di Indonesia senantiasa berpedoman pada tujuan pembelajaran inklusi yakni memberikan akses agar peserta didik anak berkebutuhan khusus memperoleh layanan pendidikan yang maksimal sesuai dengan kebutuhannya.
\end{abstract}

Kata kunci: Pendidikan Inklusi, Pendidikan Anak Usia Dini, Pendidikan

\begin{abstract}
study aims to analyze the extent of the implementation of inclusive education in early childhood education institutions in Indonesia. Inclusive education at an early age begins by accommodating the needs of children, identifying the special needs of children, and mapping the development potential and barriers of children now and in the future. Inclusive education provides opportunities for children with special needs to get an equal education. The practice of the inclusive education system implemented at the level of early childhood education still leaves problems, the implementation of inclusive education which is apparently still not inclusive. The issue of educators, supporting facilities, and inclusive education curricula in early childhood education institutions is also not yet capable Inclusive education in Indonesia must involve parents, teachers and the environment, the implementation of inclusive education in Indonesia leads to the goal of inclusive learning that provides the broadest opportunities- breadth to all children including children with special needs to get proper education in accordance with their needs.
\end{abstract}

Keywords: Inclusive Education, Early Childhood Education, Education.

Implementasi Pendidikan Inklusif (Syahria A. Sakti) 238 


\section{PENDAHULUAN}

Di Indonesia kesempatan memperoleh layanan pendidikan telah diatur dalam Undang-undang Dasar Negara Republik Indonesia (UUD NKRI) yang mengamanatkan bahwa sistem pendidikan nasional harus mampu memberikan kesempatan pada setiap warganya untuk memperoleh pendidikan yang berkualitas dan setara secara adil. Hal ini dapat diartikan bahwa jaminan kepada seluruh anak-anak termasuk anak berkebutuhan khusus untuk mendapatkan pendidikan yang berkualitas dan layak (Purnama \& Abadi, 2017). Negara kemudian mengimplementasikan jaminan tersebut dimana pendidikan inklusif didefinisikan sebagai sistem yang mengatur tentang penyelenggaraan pendidikan yang didalamnya tidak membeda-bedakan antara siswa normal dengan siswa yang berkebutuhan khusus agar mereka dapat berinteraksi dalam suatu lingkungan pendidikan secara bersamaan (Anwar \& Marhun, 2017). Atas dasar itulah konsep pendidikan inklusi senantiasa memberikan warna tersendiri bagi terciptanya akses layanan pendidikan dengan tanpa membeda-bedakan kondisi dan latar belakang dari warga belajarnya.

(Juherna et al., 2020) memberikan konsep ini merupakan konsep yang mengedepankan kesetaraan dan keadilan dalam memperoleh pendidikan, konsep ini dapat diterapkan sejak anak usia dini hingga perguruan tinggi. (Asmawati, 2014) menjelaskan bahwa dalam review yang dilakukannya, pendidikan inklusif memberikan stimulus positif karena stimulus yang diberikan jika sesuai dengan tingkat perkembangan anak akan memberikan efek yang cukup signifikan. menjelaskan bahwa strategi kegiatan pembelajaran pendidikan inklusif pada anak usia dini dimulai dengan mengakomodasi kebutuhan anak, mengidentifikasi kebutuhan khusus anak, serta memetakan potensi perkembangan dan hambatan anak saat ini maupun di masa depan. Pendidikan inklusif berkesempatan agar mampu mengidentifikasi serta mempelajari kurikulum yang tidak jauh berbeda, menemukan bahwa anak berkebutuhan khusus pada lembaga pendidikan anak usia dini yang inklusif lebih dapat bersosialisasi dibandingkan mereka yang berada di lembaga pendidikan khusus (Juherna et al., 2020; Purnama et al., 2017; Sectio et al.,2018.).

Temuan penelitian (Reefani, 2013; Windarsih et al., 2017) menemukan 3 hambatan utama terkait dengan implementasi model inklusi ini, yaitu pertama ketersediaan guru profesional pada bidang inklusi; sikap orang tua serta guru yang masih belum dapat menerima anak berkebutuhan khusus hadir ditengah-tengah mereka; dan pendidikan inklusif tak sepenuhnya inklusif. Temuan ini didukung oleh beberapa temuan penelitian yang sejenis, (Wibowo et al., 2013) menjelaskan bahwa persepsi sebagian besar wali murid 
dan guru menginginkan anak berkebutuhan khusus menempun pendidikan di sekolah khusus, (Anggraeni et al., 2019) menjelaskan bahwa TK Soroako tidak sepenuhnya menggunakan konsep pendidikan inklusi karena masih memisahkan kelas anak berkebutuhan khusus dengan siswa lainnya, penelitian Purnama \& Abadi (2017) menjelaskan bahwa masih banyak ditemukan para guru yang belum memiliki kualifikasi atau sertifikat pendidik anak berkebutuhan khusus yang menangani para siswa dengan kebutuhan khusus. Hal tersebut tentu saja menjadi sebuah tantangan ke depannya agar sistem pendidikan kita mengatur dengan jelas kualifikasi dan syarat tenaga pendidik dalan sekolah-sekolah inklusi.

Praktek sistem pendidikan inklusi yang di implementasikan pada tingkatan pendidikan anak usia dini masih menyisakan persoalan, Anwar \& Marhun (2017) menjelaskan bahwa persoalan utama adalah pelaksanaan pendidikan inklusi yang ternyata tidak inklusif. Selain itu, persoalan tenaga pendidik, sarana prasara pendukung, serta kurikulum pendidikan inklusi pada lembaga pendidikan anak usia dini juga belum mumpuni (Huda \& Iman, 2017). (Purnama et al., 2017)menyebutkan bahwa pendidikan inklusi di Indonesia harus melibatkan orang tua, guru dan lingkungan, ketiga aktor tersebut harus memiliki persepsi yang sama pada pendidikan inklusi, namun yang terjadi hanya orang tua yang memiliki persepsi positif terhadap pendidikan inklusi..

Sosialisasi dan pengembangan penelitian dibidang pendidikan inklusi sangat perlu dilakukan, akademisi perlu berkerjasama dengan tenaga pendidik dan aktor lain yang bersinggungan langsung dengan praktik pendidikan inklusi di Indonesia. Hak anak berkebutuhan khusus untuk mendapatkan pendidikan yang setara dan berkualitas seperti anak lain pada umumnya di sekolah reguler harus terus didukung. (Adiarti, 2014) menjelaskan bahwa bagi anak-anak berkebutuhan khusus yang mampu mengikuti pembelajaran di lembaga pendidikan reguler, merupakan nilai yang amat positif bagi mereka untuk dapat diterima di masyarakat dan bersosialisasi. Penelitian ini tertarik untuk menganalisis sejauh mana implementasi pendidikan inklusi pada lembaga pendidikan anak usia dini di Indonesia. Penelitian menggunakan metode literatur review dengan menganalisis penelitian terdahulu berkaitan dengan implementasi pendidikan inklusif dan evaluasinya. 


\section{METODE PENELITIAN}

Penelitian ini menggunakan metode kualitatif dengan pendekatan model studi pustaka atau library research, pendekatan ini menggunakan penelitian terdahulu, teori, pendapat ahli, dokumentasi dan literatur lainnya sebagai objek yang utama dalam penelitian. (Utarini, 2008) menyebutkan bahwa jenis penelitian kualitatif menghasilkan informasi berupa data deskriptif, catatan dan dokumen serta keterngan yang terdapat didalam teks yang diteliti. Pencarian artikel dan jurnal penelitian terdahulu dilakukan pada laman database google scholar, portal garuda dan neliti. Peneliti menggunakan kriteria inklusi dalam memilih studi yang menjadi literatur review pada penelitian ini diantaranya Penelitian berkaitan dengan tema pendidikan inklusi pada anak usia dini dan atau evalusi implementasi pendidikan inklusi pada lembaga pendidikan anak usia dini; Penelitian harus memberikan kesimpulan dan informasi yang jelas dan signifikan baik menggunakan penelitian kualitatif maupun kuantitaf.; Teks penelitian dapat berupa bahasa inggris maupun bahasa indonesia dari jurnal terpecaya dengan subyek dan obyek penelitian di Indonesia; dan Tahun penerbitan jurnal kekinian dari tahun 2012-2019. Publikasi yang tidak lengkap seperti hanya berbentuk abstrak, editorial maupun review tidak digunakan.

Pencarian literatur dilakukan pada Februari 2020, peneliti mencari menggunakan empat sumber database publikasi google schoolar, portal garuda, neliti dan proquest. Kata kunci yang digunakan oleh peneliti adalah 'Pendidikan inklusi pada anak usia dini' dan 'Implementasi pendidikan inklusi pada anak usia dini',. Pencarian dilimitasi pada jangka waktu tahun 2012-2019, guna mendapatkan sumber yang kekinian dan valid. Data Selection and Analysis Pencarian jurnal dilakukan melalui database google schoolar, portal garuda, neliti dna proquest lalu jurnal di ekstrak oleh peneliti secara indipenden. Judul dan abstrak jurnal yang disimpan dalam database internasional dicari dengan menggunakan kata kunci yang ada. Tiap database dicari dengan menggunakan kata kunci yang sama, berdasarkan pencarian ditemukan bahwa dari database Google Scholar sejumlah 12,312 publikasi, portal garuda ditemukan 129, neliti ditemukan 12, dan ProQuest 284. Dari keseluruhan database hanya 10 yang memenuhi kriteria inklusi dan diperhitungkan untuk direview dalam penelitian ini. 


\section{HASIL DAN PEMBAHASAN}

\section{Implementasi Pendidikan Inklusi pada Lembaga Pendidikan Anak Usia Dini di Indonesia}

Pendidikan merupakan aspek utama dalam mengembangkan sumber daya manusia, amanat konstitusi UUD NRI 1945 menjelaskan bahwa setiap anak berhak mendapatkan pendidikan yang setara dan layak. Termasuk anak berkebutuhan khusus, asas kelayakan dan kesetaraan menjadi pedoman dalam penyelenggaraan pendidikan inklusi. Secara spesifik terdapat perbedaan yang mendasar pada diri anak dengan kebutuhan khusus bila dibandingkan dengan kondisi rata-rata pada anak normal (Anwar \& Marhun, 2017). Pendidikan pada anak berkebutuhan khusus memerlukan berbagai komponen atau material yang lebih terperinci karena pada dasarnya anak memiliki ciri khas dan perbedaan masingmasing dalam merespons pembelajaran (Mushlih \& Munastiwi, 2019). Namun, penelitian (Juherna et al., 2020; Purnama et al., 2017)menjelaskan bahwa anak berkebutuhan khusus yang mendapatkan pendidikan inklusi memiliki kecepatan belajar yang hampir setara dengan mereka yang normal.

Implementasi pendidikan inklusi dapat dilakukan sejak usia dini, pada lembaga pendidikan usia dini. Penelitian (Windarsih et al., 2017) menemukan bahwa implementasi pendidikan inklusi di kota Cimahi telah sesuai dengan pedoman pendidikan inklusi pemerintah pusat dan daerah, namun dalam implementasinya kebutuhan akan saran prasarana perlu menjadi perhatian pemerintah. Temuan Windarsih \& Jumiatin (2017) menjelaskan bahwa pendidikan inklusi memerlukan sarana dan prasarana yang memadai, lembaga pendidikan anak usia dini minimal memiliki tenaga pengajar ahli lulusan kejuruan pendidikan Anak Berkebutuhan Khusus (ABK), memiliki tenaga shadow teacher, memiliki sarana pembelajaran yang memadai, memiliki perencanaan dan sikap uniliberalisme yang tinggi dalam menerapkan pendidikan inklusi.

Proses pembelajaran inklusi di Indonesia bertujuan guna mengatasi berbagai permasalahan pendidikan bagi anak berkebutuhan khusus melalui kegiatan belajar melalui sekolah reguler yang memberikan nilai positif pada semua kompetensi peserta didik. Pendidikan inklusi pada anak usia dini dapat menciptakan kesempatan bagi persiapan mereka hidup di dalam masyarakat (Huda \& Iman, 2017). Pemerintah pusat dan beberapa pemerintah daerah telah menyusun pedoman implementasi pendidikan inklusi pada anak usia dini, berdasarkan penelitian sebagian besar lembaga memakai konsep inklusi yang mengacu pada pedoman dari pemerintah pusat dan daerah. (Jumiatin et al., 
2020)menjelaskan bahwa jika implementasi dilakukan secara tepat maka sistem layanan pendidikan inklusi yang dirintis sejak bangku anak usia dini akan dapat mampu memberikan sumbangsihnya pada tahapan pendidikan anak berkebutuhan khusus pada jenjang pedidikan selanjutmya. Hal ini tentu cukup relevan dengan tujuan penyelenggaraan pendidikan nasional kita untuk senantiasa memberikan akses yang maksimal dan kemudahan-kemudahan bagi warga belajar tanpa melihat kondisi dan latar belakang yang dimiliki.

Pengembangan dan implementasi pendidikan inklusi terus dilakukan oleh lembaga pendidikan anak usia dini di seluruh Indonesia. (Huda \& Iman., 2017)menemukan bahwa lembaga PAUD Al- Khair telah melakukan evaluasi terkait dengan perlu adanya rencana strategis yakni evaluasi pada sistem pembelajaran, komponen yang terlibat dan juga evaluasi kegiatan agar layanan pendidikan inklusi di lembaga Paud Al-Khair Udayana Mataram bisa efektif dan sesuai dengan harapan serta visi misinya (Huda \& Iman, 2017). Berikut tabel review implementasi pendidikan inklusi pada 10 penelitian terdahulu yang tersedia:

\section{Tabel 1. Penelitian Terdahulu}

\begin{tabular}{|c|c|c|c|c|}
\hline Penulis & Tujuan Penelitian & Metode & Sampel & Hasil dan Kesimpulan \\
\hline $\begin{array}{l}\text { Windarsih } \\
\& \\
\text { Jumiatin } \\
(2017)\end{array}$ & $\begin{array}{l}\text { Implementasi } \\
\text { program yang telah } \\
\text { dijalankan di PAUD } \\
\text { inklusif kota Cimahi }\end{array}$ & $\begin{array}{l}\text { Deskriptif } \\
\text { analitis. }\end{array}$ & $\begin{array}{l}4 \text { Lembaga } \\
\text { PAUD di } \\
\text { Kota } \\
\text { Cimahi }\end{array}$ & $\begin{array}{l}\text { Pembelajaran } \\
\text { inklusif di Kota Cimahi } \\
\text { berlangsung sesuai dengan } \\
\text { peraturan } \\
\text { Pemkot Cimahi. Dalam } \\
\text { pelaksanaan } \\
\text { berbagai memuat } \\
\text { komponen kegiatan yang } \\
\text { baik. }\end{array}$ \\
\hline $\begin{array}{l}\text { Adiarti } \\
(2014)\end{array}$ & $\begin{array}{l}\text { Mengevaluasi guru } \\
\text { taman kanak-kanak } \\
\text { dalam } \\
\text { mengimplementasikan } \\
\text { pendidikan inklusi } \\
\text { melalui pengelolaan } \\
\text { kelas yang inklusi. }\end{array}$ & $\begin{array}{l}\text { Studi } \\
\text { Kasus }\end{array}$ & $\begin{array}{l}46 \text { TK di } \\
\text { Semarang }\end{array}$ & $\begin{array}{l}\text { Guru taman kanak-kanak di } \\
\text { Semarang } \\
\text { persepsi yang positif } \\
\text { terhadap pendidikan } \\
\text { inklusi, beberapa guru tidak } \\
\text { antusias dalam sosialisasi } \\
\text { dan penelitian namun tidak }\end{array}$ \\
\hline
\end{tabular}


mewakili seluruh sampel.

$\begin{array}{llll}\text { Lestari \& } & \text { Menganalisis dan Kualitatif } & \text { Paud } \\ \text { Sutarto } & \text { mendeskripsikan } & & \text { Talenta } \\ \text { (2019) } & \text { kurikulum inklusi } & \text { Semarang } \\ & \text { yang diadakan di } & \\ & \text { (Pendidikan Anak } & \\ & \text { Usia Dini) PAUD } & \\ & \text { Talenta Semarang } & \end{array}$

Terdapat akses yang adil terhadap ABK di PAUD Talenta, orang tua dan masyarakat memberikan kepercayaan penuh kepada sekolah dalam melayani ABK. Implementasi pendidikan inklusif telah sesuai dengan standar pemerintah pusat dan daerah, sarana dan prasarana sangat memadai.

$\begin{array}{llrl}\text { Anwar \& } & \text { Gambaran } & \text { Studi } \\ \text { Marhun } & \text { pelaksanaan } & \text { kegiatan } & \text { Kasus } \\ (2017) & \text { di PAUD } & \text { Kasih } & \\ & \text { Bandung beserta } & \\ & \text { implementasinya } & \end{array}$

PAUD Perencanaan melibatkan Terpadu tim ahli sehingga Kasih penyusunan dan Bunda penyesuaian materi untuk Bandung ABK dipertimbangkan sesuai dengan kebutuhan dan hambatan anak. Layanan pendidikan inklusif tidak membedakan atau bersifat adil dan setara. Sarana dan prasarana sangat memadai.

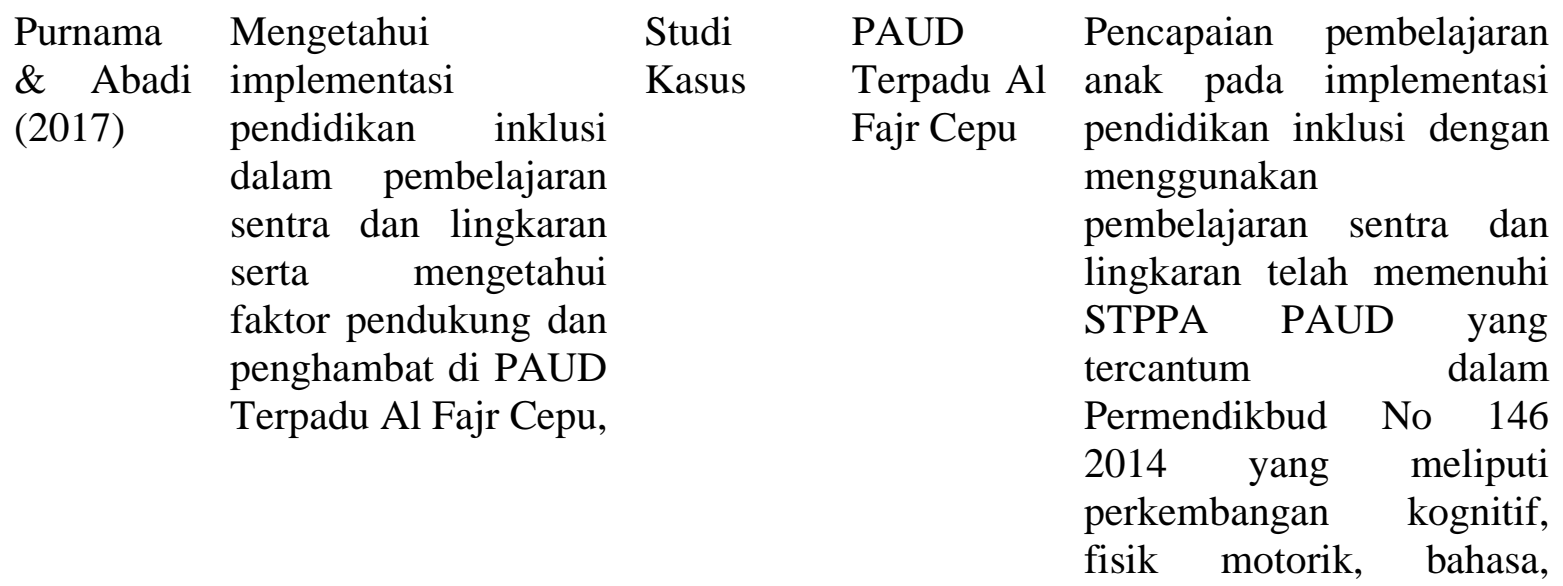




$\begin{array}{ll}\text { Mushlih } & \begin{array}{l}\text { Memberikan } \\ \text { gambaran proses }\end{array} \\ \text { Munastiwi } & \text { pelaksanaan lembaga } \\ (2019) & \text { taman kanak-kanak } \\ & \text { berbasis inklusi dan } \\ & \text { berbudaya lokal. }\end{array}$

Asmawati (2019)

Studi
Kasus

Studi Kasus

$\begin{array}{ll}\text { Studi } & \text { PAUD } \\ \text { Kasus } & \text { Bina } \\ & \text { Bangsa } \\ & \text { Islamic } \\ & \text { School } \\ & \text { kota } \\ & \text { Serang }\end{array}$

sosial emosional, moral keagamaan dan seni. Persepsi orang tua masih menjadi faktor penghambat pendidikan inklusi, ketersediaan guru profesional meningkatkan mutu pendidikan.

Tk Terdapat perencanaan dan Laboratori pembagian tugas telah Pedagogia selesai di awal semester, UNY terdapat shadow teacher Yogyakarta setelah melalui asesmen dari konselor. Proses pembelajaran bagi anak ABK dilaksanakan bersama dengan anak normal tanpa membedabedakan bentuk kegiatan.

Pelaksanaan pembelajaran dalam pendidikan inklusi di PAUD Bina Bangsa Islamic School Serang Banten telah sesuai dengan pedoman pendidikan inklusi, semua peserta didik diberikan perlakuan yang sesuai dengan kebutuhannya.

menggunakan kurikulum 2013.

Berdasarkan review diatas bisa ditarik suatu "benang merah" yakni implementasi pendidikan inklusi di Indonesia memgacu pada tujuan pembelajaran inklusi yang senantiasa menciptakan akses semaksimal mungkin agar anak berkebutuhan khusus dapat memperoleh pendidikan yang layak sesuai dengan tingkat kebutuhan pendidikan. Undang- 
Undang Dasar 1945 khususnya pasal 31 ayat 1 juga telah mengamanatkan terkait dengan pendidikan inklusi ini yakni 'setiap warga negara berhak mendapat pendidikan dan setiap warga negara mempunyai hak yang sama untuk memperoleh pendidikan yang bermutu. Dalam undang-undang tentang perlindungan anak pada UU No 23/2002, pada pasal 51 yang berbunyi bahwa anak yang menyandang cacat fisik dan atau mental diberikan kesempatan yang sama dan aksessibilitas untuk memperoleh pendidikan biasa dan pendidikan luar biasa. Pembelajaran inklusi juga telah sesuai dengan pedoman yang mengikuti asas humanisme, uniberalisme, pluralisme, demografi, dan menghormati hak asasi manusia. Harapannya layanan akan pendidikan inklusi akan dibutuhkan dan semakin dapat diterima secara luas oleh berbagai lapisan masyarakat.

\section{Hambatan dan Pengembangan Konsep Pendidikan Inklusi pada Anak Usia Dini di Indonesia}

Berdasarkan analisis yang dilakukan pada penelitian terdahulu terkait implementasi pendidikan inklusi di lembaga pendidikan anak usia dini di Indonesi maka didapatkan faktor-faktor pendukung dan penghambat. Aplikasi dan Implementasi Pendidikan inklusi Pendidikan inklusif bagi anak berkebutuhan khusus hanya sebatas dipahami oleh orang tua murid sebagai upaya memasukkan anak berkebutuhan khusus ke sekolah dalam rangka kesetaraan pendidikan saja, bukan merupakan bagian dari penerepan asas kemudahan akses, anti diskriminasi, dan jaminan pendidikan bagi setiap anak akan pendidikan di setiap jenjang pendidikan yang dibangun melalui perubahan sudut pandang para orang tua siswa. Masih ditemukan pendapat bahwa anak harus menyesuaikan dengan sistem sekolah karena banyak yang beranggapan bahwa pendidikan inklusi cenderung dipersepsi sama dengan integrasi, sehingga dalam penerapannya banyak para guru yang belum mampu bersikap ramah dan aktif terhadap peserta didiknya, sehingga menimbulkan ketidakpuasan dari wali siswa sehingga menempatkan anak sebagai bahan bullying (Adiarti, 2014; Juherna et al., 2020; Sari, 2017).

Kebijakan sekolah yang diantaranya adalah Visi dan misi masih belum jelas sehingga tidak ada perencanaan yang matang akan siapa yang dapat diterima menjadi peserta didik dan siapa yang dapat ditolak, serta sarana prasarana apa yang perlu disiapkan. Sebagian lembaga telah memiliki guru khusus yang tersertifikasi pendidikan anak berkebutuhan khusus, tetapi koordinasi yang dibangun antara pemangku kebijakan dan tenaga pendidik masih kurang sekali. Selain itu, Guru kelas kurang memiliki responsibility terhadap progress kemajuan pembelajaran siswanya karena adanya kebijakan-kebijakan 
yang kurang mendukung pelaksanaan proses pembelajaran (Lestariningrum, 2017; Mursita, 2015; Purnama et al., 2017).

Proses pembelajaran inklusi diantaranya adalah Pembelajaran seringkali dilaksanakan dalam bentuk team teaching, dilakukan secara terkoordinasi. Seringkali pemahaman yang akan disampaikan guru terbentur akan keterbatasan yang dimiliki warga belajarnya baik dalam penyampaian materi atau kurikulum dasar yang ingin disampaikan. Sebagian besar penelitian meyebutkan keterbatasan sarana pendukung pembelajaran sehingga berbagai kendala terkait dengan kesulitan belajar anak yang berbeda-beda seringkali tidak mendapatkan respon yang maksimal. Dan Sistem dukungan Sebagian besar penelitian menyebutkan partisipasi publik dan juga dukungan dari orang-orang terdekat masih sangat minim Sikap realistik atau pasrah dari orangtua siswa sehingga berdampak pada belum terbinanya keterlibatan yang maksimal dari para orangtua siswa (Juherna et al., 2020; Lestariningrum, 2017; Wuryandani \& Senen, 2018).

\section{KESIMPULAN}

Praktek sistem pendidikan inklusi yang di implementasikan pada tingkatan pendidikan anak usia dini masih menyisakan sebuah pekerjaan rumah yang berat yakni dengan ditemukannya persoalan pelaksanaan pendidikan inklusi yang ternyata masih tidak inklusif. Persoalan tenaga pendidik, sarana prasarana pendukung, serta kurikulum pendidikan inklusi belum mumpuni untuk menjawab tantangan yang ada. Agar mampu menjawab tantangan yang ada hendaknya model pendidikan inklusi di Indonesia harus melibatkan orang tua, guru dan lingkungan yang mendukung. Implementasi pendidikan inklusi di Indonesia harus senantiasa mengacu pada tujuan pembelajaran yang sesuai dengan sistem pendidikan nasional kita yakni memberikan kesempatan yang sama pada setiap warga belajarnya tanpa memandang sebelah mata dan meremehkan kondisi fisik warga belajarnya. Sejatinya pemerintah pusat dan beberapa pemerintah daerah telah menyusun pedomen implementasi pendidikan inklusi pada anak usia dini, jika implementasi dilakukan secara tepat maka sistem inklusi yang telah diselenggarakan sejak bangku usia dini akan dapat berkonstribusi secara maksimal bagi lembaga maupun peserta didiknya. Dukungan lingkungan dan kolaborasi yang baik antara pemangku kebijakan dan stakeholder yang ada dirasa mampu menciptakan rasa optimisme terkait dengan layanan pendidikan inklusi yang semakin baik lagi ke depannya. 


\section{DAFTAR PUSTAKA}

Adiarti, W. (2014). Implementasi Pendidikan Inklusi Melalui Strategi Pengelolaan Kelas Yang Inklusi Pada Guru Taman Kanak-Kanak Di Kecamatan Ngalian, Semarang. Implementasi Pendidikan Inklusi Melalui Strategi Pengelolaan Kelas Yang Inklusi Pada Guru Taman Kanak-Kanak Di Kecamatan Ngalian, Semarang, 12(1), 70-78. https://doi.org/10.15294/rekayasa.v12i1.5589

Anggraeni, D., Hartati, S., \& Nurani, Y. (2019). Jurnal Obsesi : Jurnal Pendidikan Anak Usia Dini Implementasi Metode Bercerita dan Harga Diri dalam Meningkatkan Kemampuan Berbicara Anak Usia Dini. 3(2), 404-415. https://doi.org/10.31004/obsesi.v3i2.224

Asmawati, L. (2014). Ruang Lingkup Pengelolaan Kegiatan di Lembaga PAUD. Modul 1 Ruang Lingkup Pengelolaan Kegiatan Di Lembaga PAUD, 1.2-1.54. http://repository.ut.ac.id/4719/1/PAUD4407-M1.pdf

Juherna, E., Purwanti, E., Melawati, \& Utami, Y. S. (2020). Implementasi Pendidikan Karakter Pada Disabilitas Anak Tunarungu. Jurnal Golden Age, Universitas Hamzanwadi, 04(1), 12-19.

Jumiatin, D., Windarsih, C. A., \& Sumitra, A. (2020). Penerapan Metode Holistik Integratif Dalam Meningkatkan Kecerdasan Interpersonal. Tunas Siliwangi: Jurnal Program Studi Pendidikan Anak Usia Dini STKIP Siliwangi, Bandung, 6(2), 1-8.

Lestariningrum, A. (2017). Implementasi Pendidikan Inklusif untuk Anak Usia Dini di Kota Kediri. Jurnal Children Avisory Research and Education, 4(2), 53-68.

Mursita, R. A. (2015). Respon Tunarungu Terhadap Penggunaan Sistem Bahasa Isyarat Indonesa (Sibi) Dan Bahasa Isyarat Indonesia (Bisindo) Dalam Komunikasi. Inklusi, 2(2), 221. https://doi.org/10.14421/ijds.2202

Pendidikan, P., Di Lembaga, I., Al-Khair, P., Pendidikan, M., Anak, B., Khusus, B., Huda, K., \& Iman, N. (2017). Pelaksanaan Pendidikan Inklusif di lembaga Paud Al-Khair dalam Memberikan Pendidikan Bagi Anak Berkebutuhan Khusus (ABK). Bimbingan Dan Konseling FIP IKIP Mataram, 2(April), 2503-1708.

Purnama, A., Abadi, M. I., \& Chasanah, A. (2017). Implementasi Pendidikan Inklusi Dalam Pembelajaran Sentra Dan Lingkaran Di Paud Terpadu Al Fajr Cepu. Prosiding Seminar Nasional Hasil Penelitian Dan Pengabdian Kepada Masyarakat II Universitas PGRI Ronggolawe Tuban, 2(September), 133-138.

Reefani, N. K. (2013). Panduan Anak Berkebutuhan Khusus. Free, 17.

Sari, E. P. (2017). Faktor Yang Mempengaruhi Bullying Pada Anak Usia Sekolah Di Sekolah Dasar Kecamatan Syiah Kuala Banda Aceh. Faktor Yang Mempengaruhi 
Bullying Pada Anak Usia Sekolah Di Sekolah Dasar Kecamatan Syiah Kuala Banda Aceh, 8(3).

Sectio, I., Satyani, C., Agung, A., \& Cahyadi, J. (n.d.). Perancangan Media Pembelajaran Animasi Bahasa Isyarat untuk Anak Disabilitas Tuna Rungu Usia 5-8 Tahun. 1-10. www.dit.plb.or

Utarini, A. (2008). Penelitian Kualitatif dan Paradigmanya. Magister Manajemen Rumahsakit Fakultas Kedokteran UGM, 19(5), 317-325.

Wibowo, A., Fegumi, M. A., Muchsinin, Nursidiq, F., Al-, P. H., \& Rasyid. (2013). Gerakan taman baca "perpustakaan dusun" dari mahasiswa untuk desa. Jurnal Inovasi Dan Kewirausahaan, $2(1)$ 63-67. https://journal.uii.ac.id/ajie/article/download/7851/6862

Windarsih, C. A., Jumiatin, D., Efrizal, E., Sumini, N., \& Utami, L. O. (2017). Implementasi Pendidikan Anak Usia Dini Inklusif Dikota Cimahi Jawa Barat. P2M STKIP Siliwangi, 4(2), 7. https://doi.org/10.22460/p2m.v4i2p7-11.636

Wuryandani, W., \& Senen, A. (2018). Implementasi pemenuhan hak anak melalui sekolah ramah anak. Jurnal Civics: Media Kajian Kewarganegaraan, 15(1), 86-94. https://doi.org/10.21831/jc.v15i1.19789 